\title{
DEAR MOM AND DAD
}

\author{
Justice Steven H. David*
}

Dear Mom and Dad, ${ }^{1}$

You two were the ideal role models for parents, demonstrating a total devotion to the family. You taught us to believe in ourselves, to be loyal to our beliefs, and to work hard every day. And most importantly, you told all of us kids to just do our best: "Try to do your best and that is all you can do." If I heard that once, I heard it a thousand times growing up (and was still hearing it many years into adulthood). And then, of course, the famous follow-up: "Did you do your best? If you did, then that is all you did and we are proud of you."

I have tried to write this letter a few times as I mulled over things I wanted to share with you about my experience as Chief Defense Counsel for the Military Commissions at Guantanamo Bay, Cuba. My thoughts, of course, reflect so much more than just my experience of being mobilized, because I feel like I have failed for many years to capture the words to express what you two have provided to me and instilled in me-and thus how you prepared me for what I was tasked to do. But I hope my actions reflected more favorably upon your guiding hands. I tried to do my best.

I remember when I was first contacted about the vacancy of the Chief Defense Counsel at Guantanamo Bay. I responded that I really didn't want to be the Chief Defense Counsel and asked if I could be the Chief Prosecutor instead. I was told "not to worry" because I probably wouldn't be nominated by the Army's Judge Advocate General; and even if I were nominated by the Army, the other military branches could nominate someone, too; and the Secretary of Defense's office would make the final selection anyway. So the life lesson here, that I think you both experienced, is that if someone says not to worry-worry.

Remember, Dad, when I ultimately received the final telephone call from Washington, D.C., advising me that I was going to be mobilized from my civilian position as the Circuit Court Judge in Boone County to become the Chief Defense Counsel at Guantanamo Bay? You had a little trouble understanding exactly what I was going to be doing. Well trust me, you

* Justice Steven H. David was appointed to the Indiana Supreme Court in 2010. Prior to that, he served as the Circuit Judge of Boone County, Indiana. He also has nearly thirty years of service in the United States Army's Judge Advocate General's Corps, in positions ranging from trial counsel to military judge. From July 2007 until August 2008, he served as the Chief Defense Counsel for the Military Commissions at Guantanamo Bay, Cuba.

1. This is a letter I never composed. My mother passed away during my mobilization and my father passed away shortly before his ninetieth birthday. But they, like most of us, struggled to grasp the complexities, challenges, and ramifications of Guantanamo Bay. 
were not the only one-I was still trying to understand and accept the lifechanging experience I was about to embark upon myself.

I finally said to you, a World War II B-24 bomber pilot and career Air Force veteran, "Dad, I am going to be defending the 9/11 terrorists." You hesitated for a second or two, then cracked that very subtle delayed smile and responded, "Well don't work too hard, Stevie." Within a second or two you also added, "I hope you get to play a lot of golf." It wasn't exactly the response I thought I would get, but it wasn't too far off, either.

And then you got very serious and said, "Do your duty, son. Do your duty." Again, this was not what I expected - but it was what I needed. And Mom, you said - like probably all mothers say to their soldier children-"I love you," and "be careful."

But I must tell you, Dad, I was totally unprepared for the day - many months after I returned home to Indiana and was serving again as the Circuit Court Judge in Boone County - that you said there was something you needed to talk to me about. I was worried, thinking you had received some bad medical news or that something tragic had happened to someone. Instead, you said words I will never forget. You said, "Stevie, I got to tell you, what you did in Cuba was wrong. Those people are terrorists and they don't deserve any rights at all."

I must have appeared a little stunned to you, but I remember my response was, "That's okay, Dad. It is okay. You are not the only one that feels that way. It's okay." And we never talked about it again. I deeply regret that, Dad. I am sorry.

I think it would have been a very good thing to talk to you about what I did while I was doing it - and why. And it may not have changed your mind, but maybe it would have helped you to know that I did what you and Mom always told me to do: to do the very best I could, and to do my duty.

For starters, in 2008, while mobilized, I sent a note back home to the Boone County Bar Association ${ }^{2}$ - and I should have sent it to you as well. I was trying to explain how frustrated I was with the Military Commissions and the apparent lack of concern about the lack of fundamental due process afforded the detainees and, even more basically, the fundamental human rights being stripped from some of them. We were losing sight of the Rule of Law, and I asked my fellow lawyers,

[a]fter all, isn't it all about J-U-S-T-I-C-E not R-E-V-E-NG-E? Isn't this what separates us from the uncivilized? My point is that I firmly believe that history will look back on this period and neither the wealth of our great nation nor its technological advances will define our legacy. Instead, how

2. Letter from Hon. Steven H. David to Boone Cnty. Bar Ass'n, (Nov., 2008) (on file with author). 
this period of history will be looked upon will be whether, in a time of national fear and perceived uncertainty, we followed the Rule of Law, practiced fundamental principles of Due Process, demonstrated to the world that human rights apply to all humans - not just Americans. Did we demonstrate to ourselves that we are that shining city on the hill - that great experiment - and even under most difficult times did we practice what we had been preaching to the world, or did we let fear and the fear of the Rule of Law consume us? $?^{3}$

I concluded several paragraphs later by urging them to

[a]dvocate zealously, reasonably. Always act professional, even in the most unprofessional circumstances. Try not to make it personal. Take the high road or you will look like your nemesis and no one will be able to tell you apart. Be a protector of the Constitution, our laws and our system. Be proud of our Rule of Law. Each day you are the men and women who really do make a difference in the lives of those you represent. ${ }^{4}$

And I think maybe if I had stopped to share more with you about why I believed in the Rule of Law, you might have understood it better. I probably should have explained to you how important it was that the Rule of Law be followed - especially in a place like Guantanamo. And I know you always thought it was kind of funny that I had wristbands made that said "The Rule of Law Always," but I think it's important to remind myself - and everyone I can - that without the Rule of Law, we will not survive as a democracy.

Within the last several years, I ran across the most profound definition of what the law is, and in the most unlikely place. I should have shared it with you. I think it underscores that the law affects everyone every day, and without it we are doomed: "The law is defined as the system of rules of conduct established by the sovereign government of a society to correct wrongs, maintain the stability of political and social authority, and deliver justice." 5

That kind of says it all, doesn't it? It makes no difference what someone does, or how much education they have. Everyone can appreciate

3. $I d$.

4. $I d$.

5. Lawyer, WiKIPEDIA, http://www.en.wikipedia.org/wiki/Lawyer (last updated Mar. 7, 2014, archived at http://perma.cc/Z5RM-7D2N) (emphasis added). 
and understand that definition. Dad, you spent twenty-two years in the Air Force and twenty years with the United States Postal Service, and all the while you helped to support that definition of the law. Mom, you taught us as kids to follow the rules and live good lives. And little did we realize that by doing so in our everyday lives, we-like every other law-abiding citizen in this country-were promoting the law and helping to preserve the Rule of Law.

I also should have sent you a portion of the Officer Evaluation Report Support Form ${ }^{6}$ which set forth my duties and responsibilities as Chief Defense Counsel:

Supervise and manage all defense activities, personnel and resources of the Office of the Chief Defense CounselMilitary Commissions, a unified Command. Facilitate the proper and zealous representation of all accused referred to trial before a military commission. Support the National Security Strategy of the United States by ensuring conformity with the Rule of Law and a vigorous, ethical, adversarial process that will withstand domestic and international scrutiny and enhance the global image of the United States. Monitor compliance with all rules, regulations, and instructions governing military commissions within the Office of Chief Defense Counsel. Fulfill duties under the Military Commissions Act, the Rules for Military Commissions, and the Regulations for Military Commissions. Coordinate with service TJAGs on policies and procedures affecting personnel from each branch of service. ${ }^{7}$

I am sure that you would have appreciated the magnitude of those words, but I suspect you would have had difficulty understanding the full scope of them. I certainly did at the time. And as it turned out, those 127 words were pretty significant.

Everyone understands "Supervise and manage" but "all defense activities, personnel and resources" is pretty broad. You would be proud that at least I recognized from this that the success of the Office of the Chief Defense Counsel was not dependent on my efforts alone, but on the efforts

6. Army officers' work performance is assessed on a standard form known as the Officer Evaluation Report, or “OER." See DEP'T OF THE ARMY, PAMPHLET 623-3: EVALUATION REPORTING SYSTEM, § 2-3 (2012), archived at http://perma.cc/56X9-Z26H. The OER Support Form is provided to the rated officer shortly after he or she assumes his or her duties, and includes the officer's duty description and performance objections. Id. § 2-1.

7. OER Support Form for Chief Defense Counsel Position (Sept. 17, 2007) (original completed form on file with author). 
of many dedicated men and women. I was just fortunate to be in the mix. But it still came with challenges.

For example, I remember being directed to advise the Government on what I needed in terms of personnel - a request to "tell us now what you need, and be specific!" I recall laughing out loud, because how was I supposed to know what I needed? There was no history with which to compare. So I asked to see the Prosecution's projections on their numbers of lawyers, paralegals, and staff. I was denied; told it was none of my business. Ultimately, I just said I wanted one more of everything that the Prosecution wanted.

"Facilitate the proper and zealous representation of all accused" is something that every attorney understands to be the legacy of John Adams, but also clearly understands is easier said than done. ${ }^{8}$ And related to that was my responsibility to "[s] upport the National Security Strategy of the United States by ensuring conformity with the Rule of Law and a vigorous, ethical, adversarial process that will withstand domestic and international scrutiny and enhance the global image of the United States." This became the hardest personal and professional challenge I have faced.

I tried to do exactly what you two taught me to do: to do the very best I could do, and to do my duty. But I am just not sure how well I did either of those things - I suppose history will tell.

I was the third Chief Defense Counsel (there have been three since I departed). I only reported to one person, Mr. Paul Koffsky-a career servant-leader, a civilian, who was the Deputy General Counsel for the Department of Defense. Mr. Koffsky and I didn't have many conversations during my tenure, but when I asked for his assistance he never let me down.

During one of our first conversations, in explaining his role as it related to mine, he asked if I was familiar with the British form of government. "Somewhat," I replied. He explained to me, "Steve, consider me the Queen of England and you, you are the Prime Minister." At first I

8. Long before serving as our second President, John Adams accepted the unenviable - yet inestimably important - task of defending the British soldiers charged with responsibility for the Boston Massacre. In their defense, he famously argued that

It is of more importance to the community that innocence should be protected, than it is that guilt should be punished; for guilt and crimes are so frequent in this world, that they cannot all be punished .... But when innocence itself, is brought to the bar and condemned, especially to die, the subject will exclaim, it is immaterial to me whether I behave well or ill, for virtue itself is no security. And if such a sentiment as this should take place in the mind of the subject, there would be an end to all security whatsoever.

Edmund Trowbridge, The Trial of the British Soldiers, of the 29Th Regiment of Foot, for the Murder of Crispus Attucks, Samuel Gray, Samuel Maverick, James Caldwell, ANd Patrick CARr, on Monday Evening, March 5, 1770, at 83 (2012); see also Steven H. David, The Rule of Law Always, 56 Res Gestae 46 (2012), archived at http://perma.cc/EF98-PP6K. 
thought that was really cool. It meant I was really in charge of it all.

Soon thereafter, though, it dawned on me that it actually meant I was alone. I wasn't physically alone, because I had wonderfully talented people around me, but at times it felt like it was me against them. Our caseload, personnel, office space, and challenges all increased dramatically during my tenure. Khalid Sheik Mohammed and the other 9/11 conspirators were all charged and arraigned during my tenure. We faced issues accessing our clients. And we were constantly short of resources to do our job. And when I was asked to visit the Pentagon to justify something that I had said or done, or when I pushed for more resources or more access to our clients or more flights to Guantanamo, or whatever the issue was, I truly felt alone.

Fortunately, you instilled in me a strong work ethic and stressed the importance of humility. So I surrounded myself with the most talented and intelligent people I could and took their advice more often than not. Isn't that what you taught me? "Don't be afraid to listen to others, but don't be afraid to make a decision. Just try to make the best decision you can. Don't be afraid of what anyone else thinks or says about you. Just do your best."

I never got to tell you how much I have relied upon that advice so many times in my life - as a lawyer, a Circuit Court Judge, and at Guantanamo. Too many "leaders" worry about being criticized by the media, the pundits, and the armchair quarterbacks, and no action is often times the most common course of action. But like Teddy Roosevelt said, "In a moment of decision, the best thing you can do is the right thing, the next best thing is the wrong thing, and the worst thing you can do is nothing." 9

In our office, we were under significant pressure to ensure that the detainees got the best possible defense - it was, after all, my specific duty. And the challenges we faced then may be a little different than the challenges the current Defense team faces in Guantanamo, but they were every bit as real.

Back then, the biggest fight for us was whether or not the United States Constitution even applied to the detainees. It's hard to believe that was something in contention, but it's true. Of course we now know that the Constitution does apply, but it took the United States Supreme Court to resolve this. On one side, the position was that the detainees have no rights other than those we choose to give them-the same sort of pre-Civil War approach that our country took towards African-Americans. And on the

9. This quote was attributed to President Theodore Roosevelt by John M. Kost in 1995, in testimony presented before the Subcommittee on Oversight of Government Management and the District of Columbia, a subcommittee of the Senate Committee on Governmental Affairs. S. 946, the Information Technology Management Reform Act of 1995: Hearing Before the Subcomm. on Oversight of Gov't Mgmt. and the D.C. of the S. Comm. on Governmental Affairs, 104th Cong. (1995) (statement of John M. Kost, Chief Information Officer, State of Michigan). 
other side was the position that the Constitution must apply, or else we have allowed fear of the Constitution to control. And why should we have been afraid of the Constitution?

I know you were not sympathetic to the detainees, Dad, but being the Chief Defense Counsel wasn't about sympathy for detainees. The issue was guaranteeing that their rights were protected - and ours, too. Because if we started cutting corners in Guantanamo Bay, where would it stop? So the issues weren't just about the detainees, either - the issues were about us.

Of course everyone serving at Guantanamo was under tremendous pressure, and all were trying to do the right thing. I still know many of those serving there today, and I know they all are trying to do the right thing as well. Unfortunately, we have a tendency to categorize people based upon their jobs, duties, and positions, instead of being open-minded and trying to learn more and understand more.

For example, I remember being accused of being unethical and gaming the system. Trust me, I am not that smart-nor was that how you taught me to act. But it was because I was trying to "facilitate the proper and zealous representation of all accused." In other words, it was because I was trying my best to do my duty.

In response, I took the opportunity to address all of the Prosecutors, and I talked about how we all wore uniforms that said "U.S.," meaning United States. It meant we all served our government, but in different ways. And regardless of whether we were Prosecutors or Defense Counsel, we had all taken the same oath-we were all sworn to support and defend the Constitution of the United States. My point was that but for the grace of God, each of us could be on "the other side," and each of us had an obligation to do our respective jobs - to do our duty. To do our best.

On Sunday, November 3, 2013, 60 Minutes did a story on Guantanamo Bay. ${ }^{10}$ I wish we could have watched it together. And I wish we could have talked about what happens next, because much has changed for the better at Guantanamo, but much has not. There still remain serious questions to be answered.

How do we bring this to closure? Will we just hold all the detainees without charges? Why do we even need to think about introducing statements made by detainees without the right to counsel and as a result of waterboarding? Do we think we can't prove the cases without this tainted evidence? And why do we seek the death penalty for a detainee who wants to be a martyr? Isn't that attempting to give them what they wantimmortality? Wouldn't a sentence of life in prison be the most horrible sentence they could imagine and maybe more appropriate? What are we afraid of?

10. 60 Minutes: Inside Guantanamo (CBS television broadcast Nov. 3, 2013), archived at http://perma.cc/V2KL-48HD. 
And what was wrong with the federal court system? What was wrong with the Uniform Code of Military Justice? Why did we invent a new system fraught with unknowns specifically to deal with these detainees? Why didn't we prosecute the worst of the worst for war crimes that are recognized throughout the world? Why did we try to get legally cute and creative? Hasn't that dogged us ever since we conjured up the notion that somehow the Constitution doesn't apply to those we chose to detain at Guantanamo Bay, Cuba?

And that day back in Boone County, after I came home, I should have shared with you the evaluation I received from Mr. Koffsky: "COL David took on one of the most challenging positions in International Law today and exceeded all demands." ${ }^{11}$ Or I should have shared the comments from the General Counsel for the Secretary of Defense on my service to my country:

COL David was masterful in his leadership of the Office of the Chief Defense Counsel. He led by advocating the Rule of Law and establishing faith and confidence in the ability of his office to zealously represent detainees charged under the Military Commissions Act. With the eyes of the world fixed on the United States and the world fixed upon his Office, he performed his mission superbly, resulting in not only the superior defense of those detainees who are charged but in a genuine and well-earned respect throughout the international legal community for the men and women under his command and for their work. ${ }^{12}$

I should have shared these comments with you, but not because I am anyone special. Hundreds and maybe thousands of men and women deserved - and hopefully received — similar comments and compliments.

But I missed the opportunity to help you understand that I tried to do just exactly what you two taught all of us to do - to do the very best we could do. That is all you ever asked of us; all you ever expected of us-and all we can ever really ask or expect of those around us. Who knows how well any of us did at Guantanamo, whether we were Prosecutors, Defense Counsel, or serving in connection with the Military Commissions. It certainly is impossible to wash all the dirt away from some of the bad things that have happened to some.

Nevertheless, whether lawyers or not, we were-and are - part of something that had a profound impact upon all of us personally and upon our country for years to come. It is something many would rather not talk

11. OER Support Form for Chief Defense Counsel Position, supra note 8.

12. OER Support Form for Chief Defense Counsel Position, supra note 8. 
about or think about, and something that neither our Congress nor any President has yet to fully come to grips with. It is not about a Republican thing, or a Democrat thing. It is about an American thing. It is about justice. It is about the foundation of our government. It is about our past, our present, and our future. It is about the Rule of Law.

Mom, I know you liked show tunes and big band numbers, and Frank Sinatra, and Dad, I know you were never much of a music fan at all. But I've always liked country music myself, and like the country artist Toby Keith says, there "ain't no right way to do the wrong thing."13 My time as Chief Defense Counsel for the Military Commissions at Guantanamo Bay was my duty - and it was also my duty to do the right thing, the right way. I gave it my best.

I just wish we could've talked about it.

Love,

Stevie

13. Toby Keith, Ain't No Right Way, on White Trash with Money (Slow Dog Nashville 2006) ("Ain't no right way to do the wrong thing; You can justify, but it's still black and white; Paint it any shade, but it won't change; Ain't no right way, to do the wrong thing."). 
